\title{
THE INTERNATIONAL HEALTH DIVISION OF THE ROCKEFELLER FOUNDATION AND THE TRAINING OF HEALTH PROFESSIONALS IN BRAZIL: THE CASE OF OLYMPIO DA FONSECA (1920S)
}

\author{
Ana Paula Korndörfer \\ Universidade do Vale do Rio dos Sinos - Unisinos (São Leopoldo, Brasil) \\ Email: aninha.korndorfer@gmail.com / anapk@unisinos.br \\ ORCID iD: https://orcid.org/0000-0001-8643-3867
}

Recibido: 22 marzo 2020; Aceptado: 26 agosto 2020

Cómo citar este artículo/Citation: Korndörfer, Ana Paula (2021) "The International Health Division of the Rockefeller Foundation and the training of health professionals in Brazil: the case of Olympio da Fonseca (1920s)", Asclepio, 73(1): p345. https://doi.org/10.3989/ asclepio.2021.11

ABSTRACT: Our proposal, in this paper, is to discuss the role of the International Health Division (IHD) of the Rockefeller Foundation (RF) in the training of health personnel through the fellowship program of the North American philanthropic institution and, more specifically, the Foundation's work in training professionals linked to Brazil, highlighting the case of Olympio da Fonseca. Olympio da Fonseca was an important Brazilian researcher. Among the positions held by Fonseca, we can highlight the direction of the Oswaldo Cruz Institute, between 1949 and 1953, and the organization and direction of the Brazilian Institute for Research in the Amazon (19541955). Several sources allow us to reflect on the professional trajectory of the doctor and his training from the RF fellowship, such as the record produced by the Foundation (Fellowship card) and an interview granted by Olympio da Fonseca to the Center for Research and Documentation of Contemporary History of Brazil (Centro de Pesquisa e Documentação de História Contemporânea do Brasil CPDOC) of the Getúlio Vargas Foundation (FGV) in 1977.

KEY WORDS: Rockefeller Foundation; Fellowships; Health Professionals; Brazil; Olympio da Fonseca.

\author{
A INTERNATIONAL HEALTH DIVISION DA FUNDAÇÃO ROCKEFELLER E A FORMAÇÃO \\ DE PROFISSIONAIS PARA A SAÚDE NO BRASIL: O CASO DE OLYMPIO DA FONSECA (DÉCADA DE 1920)
}

RESUMO: Nossa proposta, neste artigo, é discutir a atuação da International Health Division (IHD) da Fundação Rockefeller (FR) na formação de pessoal para a saúde através do programa de concessão de bolsas de estudos da instituição filantrópica norte-americana e, mais especificamente, a atuação da Fundação na formação de profissionais vinculados ao Brasil, destacando o caso de Olympio da Fonseca. Olympio da Fonseca foi um importante pesquisador brasileiro. Entre os cargos ocupados por Fonseca, podemos destacar a direção do Instituto Oswaldo Cruz, entre 1949 e 1953, e a organização e direção do Instituto Nacional de Pesquisas da Amazônia (1954-1955). Diversas fontes nos permitem refletir sobre a trajetória profissional do médico e sua formação a partir da bolsa da FR, como a ficha produzida pela Fundação (Fellowship card) e uma entrevista concedida por Olympio da Fonseca ao Centro de Pesquisa e Documentação de História Contemporânea do Brasil (CPDOC) da Fundação Getúlio Vargas (FGV) em 1977.

PALAVRAS-CHAVE: Fundação Rockefeller; Bolsas de estudos; Profissionais de saúde; Brasil; Olympio da Fonseca.

Copyright: (c) 2021 CSIC. Este es un artículo de acceso abierto distribuido bajo los términos de la licencia de uso y distribución Creative Commons Reconocimiento 4.0 Internacional (CC BY 4.0) 
Between 1917 and 1951, 88 researchers and professionals linked to Brazilian government institutions and/or departments received 92 fellowships from the International Health Division (IHD) of the Rockefeller Foundation (RF) to carry out studies in Brazil and abroad, in the areas of public health, nursing, medicine and biological sciences. Through the granting of fellowships, the American philanthropic institution aimed at training men and women to act in strategic positions in official health agencies or as directors and/or teachers in schools of hygiene, public health and nursing. Through occupying leadership positions in government institutions and/or departments in their home countries, the fellowship holders were able to determine institutional guidelines and priorities, reflecting some of the ideas and practices with which they had become familiar during the study period. In this article, we will discuss the role of the International Health Division of the RF in the training of health personnel through the fellowship program of the North American institution and, more specifically, the Foundation's work in training professionals linked to Brazil, highlighting the case of Olympio da Fonseca. ${ }^{1}$ We are particularly interested in understanding the activities carried out by this person during his fellowship period. Olympio da Fonseca was an important Brazilian researcher. Among the positions held by Fonseca, we can highlight the direction of the Oswaldo $\mathrm{Cruz}^{2}$ Institute between 1949 and 1953. Several sources allow us to reflect on the professional trajectory of the doctor and his training from the RF fellowship, such as the record produced by the Foundation. ${ }^{3}$ However, we highlight the interview given in 1977 by Olympio da Fonseca and today deposited at the Museum of Astronomy and Related Sciences (MAST) and at the Center for Research and Documentation of Contemporary History of Brazil (CPDOC) of the Getúlio Vargas Foundation (FGV), in which the doctor addresses, among other issues, the studies carried out from the fellowship provided by RF. ${ }^{4}$

\section{THE ROCKEFELLER FOUNDATION AND ITS FELLOWSHIP PROGRAM FOR TRAINING HEALTH PROFESSIONALS}

According to John Farley (Farley, 2004, p. 2), before the foundation of the World Health Organization (WHO) in 1948, the International Health Division of the Rockefeller Foundation was probably the most important public health agency in the world. In the same vein, Anne-Emanuelle Birn (Birn, 2006, p. 15) states that, during the first half of the 20th century, no agency had as much reach or was as active in promoting international public health as the Foundation.
The Rockefeller Foundation, an American philanthropic institution, is defined, by Lina Faria, in general, as a "charity, non-governmental organization, which uses its own resources to finance social welfare activities in several countries of the world" (Faria, 2007, p. 103, note 2). Maria Gabriela Marinho states that the Foundation "[...] is at the heart of the process that generated and constituted the field of action for what was later characterized as scientific philanthropy" (Marinho, 2001, p. 14), understood as the allocation of private resources for the production of scientific knowledge (Marinho, 2001, p. 14). The Foundation was created in 1913 with the aim of incorporating, in a single organization, institutions belonging to the Rockefeller family such as the General Education Board and the Sanitary Commission for the Eradication of Hookworm Disease. The actions of the Rockefeller family in the health area date back to 1909, the year in which the Sanitary Commission was created, a commission whose objective was to fight hookworm in southern states of the United States. ${ }^{5}$

The Division was created in 1913 with the aim of extending the Sanitary Commission's anti-hookworm disease work to other countries. The Division was called International Health Commission (IHC) between 1913 and 1916, International Health Board (IHB) between 1916 and 1927 and International Health Division (IHD) between 1927 and 1951 and, when it closed its activities in 1951, it had been present in over 80 countries worldwide, including all countries in South America. Between 1913 and 1951, the International Health Division had acted in the fight against hookworm disease, yellow fever and malaria and in other public health campaigns in the southern United States and in almost a hundred other countries around the world. During the same period, the International Health Division founded a series of schools of public health in North America, Europe, Asia and Brazil and distributed thousands of fellowships to health professionals (Farley, 2004, p. 2; Birn, 2006, p. 9).

Between the 1920s and 1960s, the Foundation helped to "[...] build and implement an extensive network of scientific institutions that enabled the diffusion and consolidation of a science model. In this sense, it is correct to say that Rockefeller's performance can be seen as decisive in the institutionalization of science on a world scale" (Faria; Costa, 2006, p. 164). The Foundation worked, with technical and/or financial resources, in the creation of medical colleges; new disciplines in the areas of pathology, anatomy, histology and microbiology; and hygiene institutes and schools of public health and nursing for the training of 
health professionals. The London School of Hygiene (England), Peking Union Medical College (China), Havana School of Surgery and Medicine (Cuba), São Paulo Institute of Hygiene (Brazil) and Anna Nery School of Nursing (Brazil) are some examples of this field of activity of the institution (Faria; Costa, 2006, p. 164; Faria, 2007, p. 80-81).

The possibility of training abroad through the granting of fellowships was an important aspect of the scientific dimension of Rockefeller's operations. At the global level, the Foundation pioneered the granting of fellowships for medical science and public health (Faria; Costa, 2006, p. 163-164; Faria, 2007, p. 79).

For Wickliffe Rose, Director of IHD between 1913 and 1923, professional education was an essential component for the advancement of public health at the international level. In Rose's conception, a select group of specialists in public health would disseminate the knowledge acquired in their respective countries through research, administration and teaching. In the interpretation of Anne-Emanuelle Birn (Birn, 2006), this approach would not only save financial resources, allowing the Foundation to implement programs in a greater number of places, but also international fellowship holders would be in a better position in relation to representatives of the Rockefeller Foundation to disseminate, in a relevant way, theories, practices and values to researchers, government agencies, professional communities and the general public. Having established links with leading universities in the United States - such as Harvard, Yale and Johns Hopkins -, the fellowship holders, upon returning to their countries of origin, would maintain a relationship with North American institutions and ideas during their professional trajectories. Still according to Birn, among the "possible" advantages of the distribution of fellowships would be the development of relationships with leaders and future leaders from other countries and the international scientific exchange (Birn, 2006, p. 197).

\section{According to Marcos Cueto and Steven Palmer}

One presumption that came with the awards was that the fellows, once back home, would reproduce the U.S. model of medical education, public health, and scientific research (often taking as the prototype Johns Hopkins University, not only a model on which many U.S. schools refashioned themselves but also the institution where many of the Latin American RF fellows trained) (Cueto; Palmer, 2015, p. 118-119).
One result of these fellowships was, according to the researchers, the increased influence of the United States in relation to France and Germany, considered by some to be the Mecca of medical studies.

Through the granting of fellowships, RF aimed at training people to act in strategic positions in official health agencies or as directors and/or teachers in schools of hygiene, public health and nursing. Through occupying leadership positions in government institutions and departments in their home countries, the scholarship holders were able to determine institutional guidelines and priorities, reflecting some of the ideas and practices with which they had become familiar during the study period. In this sense, as Birn points out, the fellowship holders were transnational professionals, moving ideas and practices across borders. The direct or indirect influence of the fellowship holders could be felt for many decades, since, in addition to guiding work in health institutions and/or departments, they were also often teachers in their countries, thus influencing other generations of public health officials (Birn, 2006, p. 201). Through the fellowship holders, the Foundation could have a lasting effect on public health theory and practice in the different countries and regions in which it operated (Birn, 2006, p. 215).

In a June 1924 document entitled "Information concerning fellowships awarded by the International Health Board of the Rockefeller Foundation ${ }^{6 \prime}$, the Foundation's New York office stated that

Fellowships granted by the International Health Board are designed to meet definite needs in public health service. They are granted only to persons carefully selected for the work that needs to be done and with the understanding that the persons receiving them will, on the completion of their training, be appointed to important positions in the official health services of their own country or in schools of hygiene ${ }^{7}$.

The RF aimed, as we have already pointed out, the training of personnel to work, in their countries of origin, in strategic positions in official health agencies or as principals and/or teachers in schools of hygiene, public health and nursing. ${ }^{8}$ Among the requirements to apply for a fellowship were high professional and scientific qualifications, as well as reliability and leadership qualities. The fellowships would be distributed, preferably, to applicants under the age of 35 . The preliminary selection was carried out by the local representatives of the RF, in agreement with the official health authorities. Applications and required documentation were then sent to the New York office for 
the final decision. The documentation included personal history on a form to be provided by the Foundation, medical examination by a trusted professional, a statement of special courses in medicine, science and public health carried out by the candidate, a list of their publications on medical and scientific topics, a statement of their professional experience since their doctorate (in the original, "since receiving the doctorate"), as well as a statement of subjects that the candidate wanted to study from the fellowship. That is, the candidate should have already completed formal education. The fellowships could have varied duration, not exceeding one year. Extensions were subject to a satisfactory record and recommendations from those responsible for the appointment. The Foundation reserved the right to cancel the fellowship in the event of conduct deemed inappropriate or detrimental to the Foundation's objectives. ${ }^{9}$

\section{THE IHD AND THE TRAINING OF PROFESSIONALS LINKED TO BRAZIL - THE CASE OF OLYMPIO DA FONSECAA}

Brazil received technical and financial support from the International Health Division of the Rockefeller Foundation in staff training. Dozens of countries counted on the cooperation of the Rockefeller Foundation, but, according to authors like Lina Faria, "Brazil was the country in the American continent in which Rockefeller invested the largest amount of capital. Out of around 13 million dollars, applied to health and education programs in countries of this continent, seven million were directed to the development of medical education, scientific research and health campaigns in Brazil" (Faria, 2007, p. 18). To exemplify, the Foundation acted, in the country, in the fight against hookworm disease (1916-1923), malaria (1919-1928) and yellow fever (1923-1940). ${ }^{10}$ With regard specifically to fellowships, several authors highlight the high number of fellowships granted by the Rockefeller Foundation to Brazil in the Latin American context (Faria, 2007; Löwy, 2006; Cueto, 1994). Analysis of the information contained in a directory of RF fellows between 1917 and 1970 - The Rockefeller Foundation. Directory of Fellowships and Scholarships (1917-1970). Nova York: The Rockefeller Foundation, 1972 - indicates, however, that the number of fellowships awarded by IHD to Brazil was significant not only in the Latin American context, but in the general context: out of the total of 2,056 fellowships distributed by IHD to professionals from more than 80 countries between 1917 and 1951, 92 fellowships (4.4\%) were awarded to professionals working in the country (Korndörfer, 2013, p. 286).
This number may appear small at first glance, which makes an observation necessary here. Out of the total of 2,056 fellowships, distributed among 1,990 fellowship holders ( 64 fellowship holders received two fellowships each and one received three), 622 (30.2\%) were awarded to professionals working in the United States; 207 (10\%), to professionals who worked in Canada and 114 (5.5\%), to professionals who worked in India. Brazil, with its 92 fellowships (4.4\%), occupied the fourth place in a list composed, remember, by more than 80 countries. Adding the fellowships received by professionals working in the United States, Canada, India and Brazil, we will obtain a total of 1,035 fellowships distributed to professionals working in four countries, that is, more than half of the fellowships (50.1\%). Mexico, the second Latin American country in number of fellowships awarded by the International Health Division, occupied the 6 th place in the overall table, with 68 fellowships (3.3\%), followed by Venezuela, in 8th, with 44 fellowships (2.1\%) (Korndörfer, 2013, p. 286).

Luiz Antonio de Castro Santos and Lina Faria affirm that, if there were positive and lasting effects of the action of the Rockefeller Foundation in Brazil, these effects were mainly concentrated "on the establishment of the roots of medical education and health professions". According to the authors, "the origins of medical, sanitary and nursing professionalization in public health [...] are strongly associated with the work of this institution in Brazil" (Castro Santos; Faria, 2004, p. 124).

The first professional who worked in Brazil to receive a fellowship from the International Health Division was Carlos Pinheiro Chagas, in 1917. After him, another 87 individuals linked to institutions and/or government departments in the country received, between 1917 and 1951, fellowships from IHD, totaling 88 fellowship owners who received 92 fellowships, since four fellowship owners (Nuno Guerner, Edith Fraenkel, Zilda Almeida Carvalho Hughes and Alayde Borges Carneiro Paraense) received two fellowships each. Olympio da Fonseca, linked to the Oswaldo Cruz Institute, received a fellowship in 1920 and carried out studies in the United States and France.

Olympio Oliveira Ribeiro da Fonseca was born on May 7, 1895 in Rio de Janeiro, then the Federal District. He was the son of Olympio Arthur Ribeiro da Fonseca, Perpetual Secretary of the National Academy of Medicine, and Eliza Oliveira Ribeiro da Fonseca. He carried out preparatory studies at the National Gymnasium, later named Colégio Pedro II. In 1913, Olympio da Fonseca enrolled in the Application Course at the Oswaldo 
Cruz Institute $(\mathrm{OCl})$, where he coexisted with Carlos Chagas $^{11}$ and Adolpho Lutz ${ }^{12}$, among others. The following year, he graduated in Microbiology and Medical Zoology from the OCl course. In 1915, he received a doctorate in Medicine from the Faculty of Medicine of Rio de Janeiro with the thesis "Studies on the parasitic flagellates". He received the Gunnin Award from the same Faculty.

A year after graduating, Olympio da Fonseca served as Field Director at the Rockefeller Foundation in Rio de Janeiro. ${ }^{13}$ In a letter from the Foundation's representative in the country, Lewis Hackett, to the director of the International Health Division, Wickliffe Rose, in 1916, Hackett stated that Fonseca, linked to the Oswaldo Cruz Institute, was appointed as his medical assistant. ${ }^{14}$ According to Olympio da Fonseca, his name was an indication of Carlos Chagas (Fonseca Filho, 1985, p. 06, 26, 36 and 37)..$^{15}$ According to Fonseca, acting as Field Director would have influenced the granting of the fellowship a few years later (Fonseca Filho, 1985, p. 36-37).

Between 1917 and 1923, Fonseca served as assistant and deputy assistant at Oswaldo Cruz Institute. In 1919, there was a first attempt to grant a fellowship to Fonseca. In a document produced by RF, we read the following information: " $F$ is Asst. to Dr. Carlos Chagas, Dir. of Oswaldo Cruz Inst., Rio de Janeiro, and is especially interested in physiological chem. and immunology. Is now devoting his time to medical science intimately related to p.h. [public health] work. Dr. Hackett states F. represents best that Brazil can offer both from point of view of scientific training and of intellectual capacity. Advisory Com. also recommends F. Upon returning to Brazil he would retain connection with Oswaldo Cruz Instit."16. As you can see, Hackett, with whom Olympio da Fonseca had previously worked, strongly supported the granting of a fellowship to the doctor, then assistant to Carlos Chagas at the $\mathrm{OCI}$.

The selection of professionals who would receive the IHB fellowships took place in partnership with health professionals and Brazilian doctors. The analyzed documentation indicates the existence of a Committee composed of Brazilian doctors - Brazilian Advisory Committee on Traveling Scholarships - that also participated in the selection process for fellowship candidates. ${ }^{17}$

A letter written by Hackett in January 1921 highlighted two aspects considered in the selection process for fellowship holders. The first aspect concerned the area of study selected by the candidate, an issue that, in Hackett's opinion, could be analyzed by the Interna- tional Health Board office in New York. In the words of the Foundation's representative in Brazil,

Two questions arise with regard to every candidate, one of which the Board is competent to decide, the other it is not. The first is whether the field of study selected by the candidate is an important one to be developed at this time and whether the position which the candidate will return to Brazil to occupy is one with sufficient authority and influence to warrant the expenditure of the Board's money in the man's training. The Board can freely make its decision on this matter without causing the least embarrassment to anyone. ${ }^{18}$

As you can see, it was necessary for the area of study selected by the candidate to be considered important by the Foundation, as public health was at that time, for example. In addition, the candidate was expected to occupy a position of "sufficient authority and influence" when they returned to the country to justify the Foundation's expenditure on their training. The fellowship holders, when returning to the country of origin, should occupy positions of responsibility.

Another aspect considered in the selection of fellowship holders was the candidates' personal fitness, and in this regard, Hackett stated that the opinion of Foundation employees in the country should be taken into account. There was a concern, on the part of the International Health Board, to be guided by universalist criteria in the selection of fellowship holders, thus avoiding the influence of political favoritism, as evidenced by Hackett in the following excerpt:

The second question refers to the candidate's personal fitness and in this, I submit, the Board must be guided by the opinion of those of us who are in Brazil and are thoroughly disinterested in the matter. No amount of references or estimates of the candidate's ability by local committees composed of disinterested people can take the place of first-hand knowledge of the man gained by conversations with those who know him best. I would go so far as to say that the written documents which a candidate can assemble should be given very little weight indeed even if emanating from the highest sources, and to refuse a man on the basis of any such documents would be impossible. I myself have just had the occasion to quash the candidacy of a thoroughly worthless individual who had actually succeeded in getting not only the most exalted references but even the approval of the Advisory Committee. The man had a powerful friend whom no one cared to offend. I stopped the matter by announcing that the field of study which the candidate intended to explore was one of minor interest and that in view of the fact that there were more 
candidates than could possibly be accepted it would be useless to carry the matter to New York. ${ }^{19}$

In Hackett's opinion and experience, little value should be attached to the letters of recommendation obtained by candidates in the selection process. Prior authorization from the IHB office in New York was necessary for Hackett to award fellowships. ${ }^{20}$

Returning to the Olympio da Fonseca's record notes, we observed that the doctor was considered by Lewis Hackett "the best that Brazil could offer in terms of scientific training and intellectual capacity". Fonseca was dedicated to the medical sciences in his relationship with public health work, an area of great interest to RF at that time. After the fellowship period, he should maintain a link with the $\mathrm{OCI}$.

But Olympio da Fonseca was unable to benefit from the fellowship in 1919, as he was requested by the federal government to act as an inspector for the Federal Sanitary Commission to combat yellow fever. In 1920, however, the scholarship was again awarded to Fonseca, then 24 years old. ${ }^{21}$ The doctor arrived in the United States on January 9, 1920, armed with a letter addressed to William Welch, whom he was supposed to address at the Johns Hospkins School of Hygiene and Public Health, in Baltimore, to discuss his studies. Using the Fonseca record again, we find the following information: " $F$ has had advanced training in medical natural history, medicine and parasitology. Has had 6 yrs. exper. in Oswaldo Cruz Inst. Hopes to obtain advanced work in Mycology". ${ }^{22}$ A doctor with experience in medicine and parasitology, Fonseca sought improvement in mycology ${ }^{23}$. The Johns Hopkins School of Hygiene and Public Health, the destination of the Brazilian physician, was the first public health school in the United States. Elizabeth Fee highlights the importance of this institution:

As the first independent, degree-granting institution for research and training in public health, the School of Hygiene was crucial to the process of professionalization of public health in the United States. As a leading research center, it helped shape the form and content of public health by developing new scientific knowledge, generating organized research, and training highly educated personnel to put this knowledge into practice. As a center for training international public health officers, it influenced the development of public health activities around the world (Fee, 1987, p. 1).

The first and largest in a series of public health schools created in the United States and abroad with investments from the Rockefeller Foundation, the
Johns Hopkins School of Hygiene and Public Health was a model for other institutions, influencing public health and its professionalization "around the world" in the 20th century (Fee, 1987, p. 1). William Welch, whom Fonseca should address, was a professor of pathology and dean at Johns Hopkins Medical School, as well as an administrator at the International Health Board. At Johns Hopkins, Fonseca worked in the pathology laboratory with William George MacCallum ${ }^{24}$. The activities carried out by Olympio da Fonseca were praised by MacCallum: " $F$ very intelligent and diligent in carrying out plan suggested for him at Hopkins, i.e. study of many forms of fungus concerned with disease production. He learned technic of growing them and did that neatly and well ${ }^{25}$. According to Fonseca's perception, MacCallum was "the greatest American pathologist at the time" (Fonseca Filho, 1985, p. 16). In Baltimore, the Brazilian doctor also worked with Thomas Casper Gilchrist, professor of dermatology at Johns Hopkins and the University of Maryland.

In April 1921, Fonseca was sent to Washington to work with Erwin Smith ${ }^{26}$, a pathologist at the Bureau of Plant Industry (U. S. Department Agriculture) ${ }^{27}$. According to Fonseca, the period of work in Washington was justified by the fact that he needed a "notion of plant pathology" and Smith "had created the bacteriology of plant diseases" (Fonseca Filho, 1985, p. 16-17). Between July and September 1921, Fonseca worked at the Bureau of Chemistry com Charles Thom (U. S. Department of Agriculture). ${ }^{28}$ The research developed by Erwin Smith and Charles Thom was considered important by Olympio da Fonseca. According to the doctor:

I learned a lot from Erwin Smith. One problem that he studied and that I came to study later was that of parasitic tumors of plants, at that time compared to those of human cancer. So, I also worked on the subject of plant cancers produced by pseudomonas tumefaciens. These mushrooms are very important because they are very common and intervene in many things. There is a group at the Bureau of Chemistry in Washington, which included Professor Charles Thom, a great expert on the subject. Charles Thom, throughout his life, studied aspergillus and penicillus from the chemical point of view and from the point of view of industrial fermentations (Fonseca Filho, 1985, p. 17).

In July 1921, Olympio da Fonseca's fellowship was renewed by the Rockefeller Foundation, but this time, to study in France, with Raymond Jacques Adrien Sabouraud ${ }^{29}$, Director of Laboratory at Hospital Saint-Louis. According to Fonseca, there was an understanding, on the part of the Foundation, that 
Picture 01 - Olympio da Fonseca in Baltimore, United States (1921). Source: MAST, OF.F.0095.0001. Olympio da Fonseca (standing, the first from left to right) and MacCallum (seated, the third from left to right) appear in the photo.

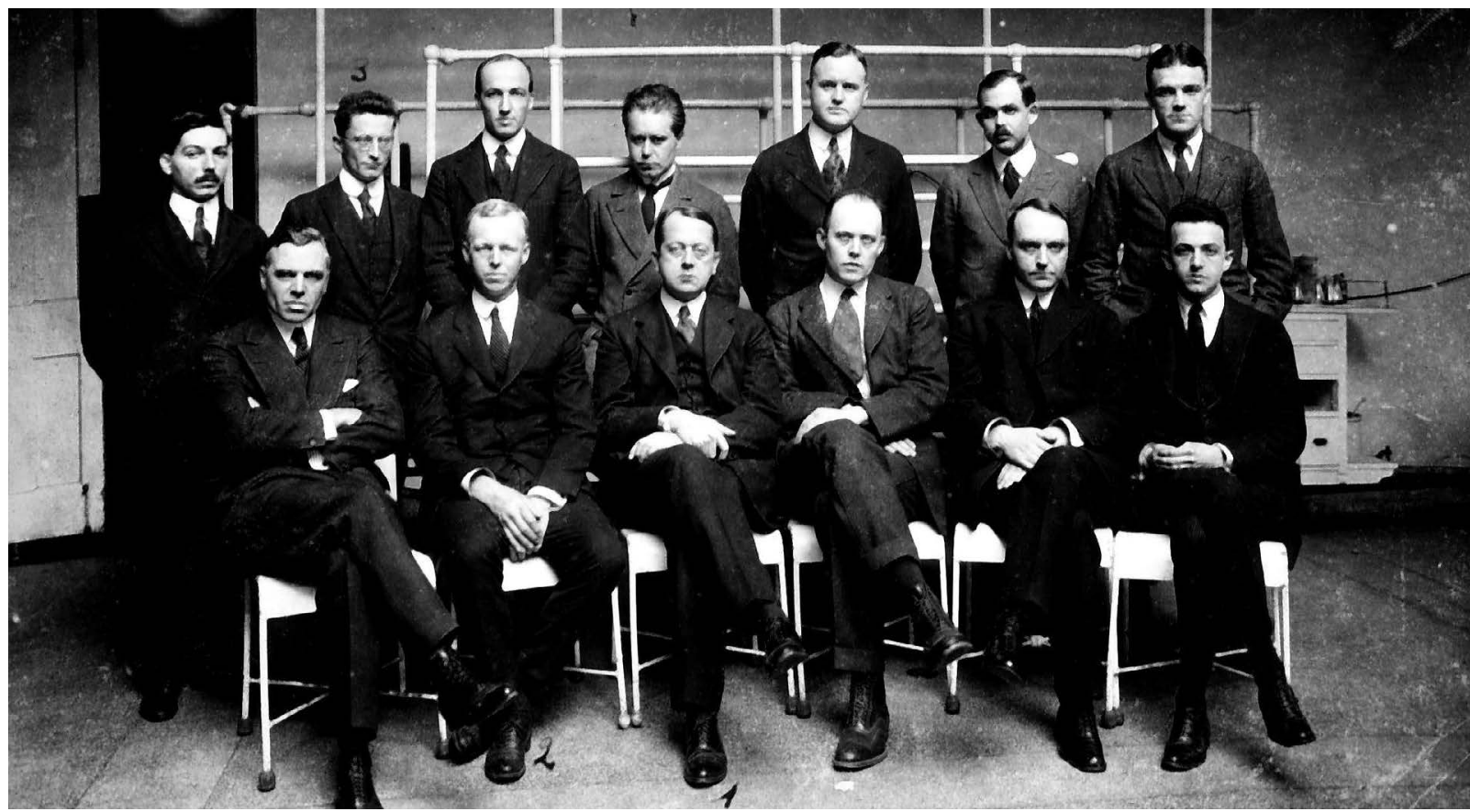

the learning of the Brazilian researcher in medical terms had not been satisfactory (Fonseca Filho, 1985, p. 22). In the record of Olympio da Fonseca, we find the following note regarding the issue: “(...) that type of work [the study of fungi in relation to diseases] seems very important in Brazil, and it would be hard to find any one else with same amount of interest in the subject combined with F's ability". ${ }^{30}$ In addition to activities with Sabouraud, Fonseca also worked at the clinic with Alexandre Joseph Émile Brumpt ${ }^{31}$ and with Maurice Charles Pierre Langeron ${ }^{32}$ at the School of Medicine. According to Fonseca, the activities carried out in France were part of a program aimed at organizing a Mycology section in Brazil. The program provided him with great learning and socializing with researchers from different parts of the world, such as Masao Ota ${ }^{33}$ (Fonseca Filho, 1985, p. 23-24). In addition to Paris, Fonseca also visited Lion. Before returning to Brazil, in 1922, he visited laboratories in England, Belgium, Netherlands and Germany. With regard specifically to the work carried out in France, Fonseca's record contains the following annotation: "Report on work done in France: In Dr. Sabouraud's lab where most of work was done, he succeeded in collecting one of the most complete collections of fungi cultures in existence. In Dr. Brumpt's dept. studied literature on subject of fungi (...)" ${ }^{34}$ Upon arriving in Brazilian lands, in the year of the centenary of in- dependence, the doctor brought with him an important collection of fungi ${ }^{35}$; according to RF, one of the most complete existing at that time.

Carlos Chagas supported the activities developed by Olympio da Fonseca on his return to the country, ordering books and providing an assistant for the organization of the collection of Mycology at the $\mathrm{OCl}$, according to Fonseca, the second in the world, behind only that of the British Institute, in London. Fonseca provided cultures to several researchers, including his masters in Paris, such as Brumpt (Fonseca Filho, 1985, p. 29). Analyzing his training in the United States and France through the RF fellowship, Olympio da Fonseca found it quite satisfactory: “(...) the interest of the Institute [Oswaldo Cruz] was more of a medical interest. There were people who had worked with Mycology here, such as Pedro Severiano de Magalhães and several others, but in isolated matters, with no one having the specialist training. I acquired this training, in part, in the United States and completed it in Europe. (...) I was lucky to work with these people [French researchers, like Sabouraud], who are of the highest order, just as I had in the United States in relation to the Johns Hopkins people" (Fonseca Filho, 1985, p. 40- 41).

Olympio da Fonseca passed away on April 19, 1978 and, throughout his professional career, he held various positions and performed numerous activities. In 1922, 
when he returned to Brazil, Fonseca founded the Mycology section and the respective fungi collection of the Oswaldo Cruz Institute. He was the director of both until 1937. He was a professor of Mycology at the Application Course of the $\mathrm{OCl}$ in the same period. From 1926 to 1927 , in a Mission of the League of Nations Hygiene Committee, he visited countries in the Far East (Japan, China, Taiwan, Indochina, Malaysia and India) and South Africa. In 1929, he became a full member of the National Academy of Medicine. Between 1933 and 1936, he was assistant and head of the Dermatological and Syphiligraphic Clinical Laboratory of the Faculty of Medicine of Rio de Janeiro. In 1933, he became professor of Parasitology at the same Faculty. Between 1949 and 1953, he directed the Oswaldo Cruz Institute. Fonseca also organized and was the first director of the Brazilian Institute for Research in the Amazon (1954-1955) ${ }^{36}$.

In terms of international projection, Fonseca was a member of several academies and societies, such as the Mycological Society of France and the Royal Academy of Medicine of Belgium. He was President of the $V$ International Congress of Microbiology, held in Rio de Janeiro in 1950, and Honorary President of the sixth and seventh editions, held in Rome (1953) and Stockholm (1958), respectively. In addition to several books, Olympio da Fonseca published dozens of works on different topics: protozoology, poisonous fishes, flu, yellow fever, bacterial plant tumors, history of medicine and science and mycology. ${ }^{37}$

\section{FINAL CONSIDERATIONS}

Returning to the objectives of the Rockefeller Foundation's fellowship program - the training of personnel to act, in their countries of origin, in strategic positions in official health agencies or as directors and/or teachers in schools of hygiene, public health and nursing -,

\section{NOTAS AL FINAL}

1 The reflections presented here were elaborated within the scope of the project "Philanthropy and international scientific cooperation: the Rockefeller Foundation and the training of senior employees for public health in Brazil (1917-1951)". The objective of the project is to analyze the Rockefeller Foundation's performance in the training of public health staff in the first decades of the 20th century, mainly through the distribution of fellowships, through which the North American institution sought to disseminate ideas and models, and its relationship with the development of public health institutions and policies in Brazil. By conducting a prosopographic study that takes as an object the 88 Brazilian fellowship holders of the Rockefeller Foundation's Inter- we believe it is possible to infer that the Foundation considered Olympio da Fonseca a successful case. When he effectively received the fellowship in 1920, Fonseca was linked to the Oswaldo Cruz Institute, an important Brazilian scientific institution. His nomination for the fellowship was made by Carlos Chagas, director of the Institute, and the candidate was positively evaluated by the RF. The activities carried out abroad, especially in France, were part, as we have seen, of a program aimed at organizing a Mycology section in Brazil.

When he returned to the country in 1922, Fonseca brought with him, in addition to the knowledge acquired (he was a specialist in Mycology) and international experience, an important collection of fungi, one of the most complete in the world at the time. Olympio da Fonseca returned to work at the Oswaldo Cruz Institute $(\mathrm{OCl})$, as expected by the Foundation. At the Institute, Fonseca organized the collection of Mycology and also taught the subject as a teacher in the Application Course between 1922 and 1937, possibly disseminating part of the knowledge acquired from the fellowship. The researcher ran the OCl between 1949 and 1953. According to Fonseca, after his return to the country, he maintained contacts and exchanges with several researchers, including his professors in France, to whom he sent samples of the Institute's fungi collection. In this sense, we can highlight the participation of Olympio da Fonseca in the French Mycological Society, reinforcing his insertion in international scientific networks. Currently, the Mycology section reorganized by Fonseca constitutes the Laboratory of Taxonomy, Biochemistry and Bioprospecting of Fungi of the Oswaldo Cruz Institute/Oswaldo Cruz Foundation (LTBBF/IOC/Fiocruz $^{38}$, and the collection brought in 1922 started the Filamentous Fungus Culture Collection (CCFF) ${ }^{39}$ of $\mathrm{OCl}$, which gathers approximately 2,100 strains of fungi from different taxonomic groups and constitutes a center for the conservation of biological resources. national Health Division, between 1917 and 1951, it is possible to discuss, among other aspects, the selection process of these fellowship holders by the Foundation and their profile, as well as their professional trajectory. In 2018 and 2019, the project was supported by the Research Support Foundation of the State of Rio Grande do Sul (FAPERGS - Notice 01/2017 - ARD).

2 In May 1900, the Federal Soroterapic Institute was created, a laboratory whose objective was to produce serum in order to combat the bubonic plague that threatened Rio de Janeiro, then Federal Capital. The laboratory was installed on the Manguinhos farm, far from the city due to the population's fear of contagion of diseases. Pedro Affonso Franco, owner of the Municipal Vaccine Institute and author of the 
project for the creation of the laboratory, was appointed administrative director of the Institute. Oswaldo Cruz was responsible for technical direction. In 1900, for political reasons, the Institute became the responsibility of the federal government, being funded by the Ministry of Justice and Interior Affairs. The Federal Soroterapic Institute was inaugurated on July 23, 1900. In December 1902, the Baron of Pedro Affonso requested removal due to the technical and administrative disagreements between him and Oswaldo Cruz, who then assumed the general direction of the Institute. In 1903, Oswaldo Cruz was appointed to the General Management of Public Health. In the same year, work began on the construction of the architectural complex of Manguinhos. The main building, the Pavilhão Mourisco, was completed only in 1918. In 1907, the Federal Soroterapic Institute changed its name to Institute of Experimental Pathology. The following year, 1908, it received the name of Oswaldo Cruz Institute, after the award obtained by Cruz at the Demography and Hygiene Exhibition held in Berlin. In 1909, the Institute started to publish the Memórias do Instituto Oswaldo Cruz magazine, an important biomedical research magazine in Latin America. In 1917, with the death of Oswaldo Cruz, Carlos Ribeiro Justiniano Chagas became the director of the Institute. After 1931, the Institute became subordinate to the Ministry of Education and Public Health, losing autonomy and suffering greater external political interference. The administrative regime of the Oswaldo Cruz Institute was radically modified in 1970 . From the decree of May of that year, the Institute was transformed into a direct administration agency of the Ministry of Health and into a private law entity, becoming a Foundation. Several institutions related to the Ministry of Health were brought together in the current Oswaldo Cruz Foundation, such as the Oswaldo Cruz Institute and the National School of Public Health, for example. The information presented here about the Oswaldo Cruz Institute is available, in more detail, in the Historical-Biographical Dictionary of Health Sciences in Brazil (Dicionário Histórico-Biográfico das Ciências da Saúde no Brasil). Instituto Oswaldo Cruz, Dicionário Histórico-Biográfico das Ciências da Saúde no Brasil (1832-1930), [online], available at: http://www.dichistoriasaude.coc.fiocruz.br, [accessed 12/15/2011].

3 Cf. Rockefeller Archive Center. RAC, RF, RG 10.2 Fellowship Recorder Cards, Series MNS Brazil.

4 Fonseca Filho, Olympio Oliveira Ribeiro da (1985), Olympio Oliveira Ribeiro da Fonseca (depoimento, 1977). Rio de Janeiro, FGV/CPDOC - História Oral. The interview was conducted in the context of the "History of Science in Brazil" project, carried out between 1975 and 1978, coordinated by Simon Schwartzman, with the support of the Financier of Studies and Projects (FINEP). The transcript is available for consultation on the FGV website (available at: https://www. fgv.br/cpdoc/historal/arq/entrevista518.pdf) and at the Museum of Astronomy and Related Sciences (MAST), Olympio da Fonseca Fund.

5 Analysis of the Rockefeller Foundation's context of creation can be found, for example, in Birn, 2006; Palmer, 2010 and Cueto; Palmer, 2015

6 "Information concerning fellowships awarded by the International Health Board of the Rockefeller Foundation". Acervo Histórico da Escola de Enfermagem Anna Nery - Univer- sidade Federal do Rio de Janeiro, Centro de Documentação, Caixa 09, Doc. 57, 1924

7 “Information concerning...", 1924, p. 1.

8 The objectives of the Foundation's fellowship program are also expressed in the History of the Fellowship Program at the Rockefeller Foundation: "Thus the functions of the Rockefeller Foundation (RF) fellowship program have been to select individuals of outstanding promise in the fields of interest defined by the general program of the Foundation, and to help to prepare individuals to make significant contributions to research and teaching or public health in the future". RAC, RF, RG 10.2, Fellowship Recorder Cards.

9 "Information concerning...", 1924.

10 The Rockefeller Foundation's activities in Brazil and the investments made in the country already in the 1910s are linked to several factors, among which the friendly diplomatic relations between Brazil and the United States in the period, the leadership position in the South American continent attributed to the country and the profound impression that the work carried out by Oswaldo Cruz against yellow fever and bubonic plague had caused in the members of the Foundation. In addition, Marcos Cueto affirms, based on the RF documentation analysis, that the choice of Brazil suggests that the institution sought to establish programs in Latin American countries that presented less obstacles to the effective implementation of new public health measures and where employees from the Foundation expected a good reception from government bureaucracy and medical elites (Castro Santos, 1989, p. 105 apud Castro Santos; Faria, 2003, p. 49-50; Cueto, 1994).

11 Carlos Chagas was born in the city of Oliveira, state of Minas Gerais, in 1879. Son of a farmer, he obtained the title of Doctor of Medicine from the Faculty of Medicine of Rio de Janeiro in 1903. His career was marked by the discovery, in 1910, of Chagas disease. In 1907, he joined the staff of the Oswaldo Cruz Institute, where he worked throughout his life and organized installations in several sections, such as that of pathological anatomy. In 1912, he received the Schaudinn Award from the Hamburg Institute for Tropical Diseases. In 1917, with the death of Oswaldo Cruz, he took over the direction of the $\mathrm{OCl}$. He was also a professor at the Faculty of Medicine of Rio de Janeiro. He died in 1934. Personalidades, Carlos Chagas, [online], available at: http://www.ioc.fiocruz.br/pages/personalidades/CarlosChagas.htm, [accessed 02/04/2020].

12 Adolpho Lutz (1855-1940) was the son of the Swiss couple Gustav and Mathilde Lutz. Born in Brazil, Lutz studied in Switzerland. In 1874, he began his higher studies, becoming a doctor in 1879. In 1880, Lutz became a doctor of medicine, with a thesis on the therapeutic effects of quebracho (a plant). In 1893, the doctor was appointed deputy director of the Bacteriological Institute of São Paulo. At the end of the same year, Lutz was appointed interim director and, in 1895, he was hired in the position. In 1908, Lutz transferred to the Oswaldo Cruz Institute. Adolpho Lutz died in Rio de Janeiro in 1940 , just before he turned 85 . The brief information presented here about Adolpho Lutz is found in Benchimol (2003).

13 Between 1916 and 1923, eleven Brazilian states and the Federal District counted on the cooperation of the International Health Board of the Rockefeller Foundation to combat a rural endemic: hookworm disease. On these cooperation agreements and the activities carried out, see Korndörfer, 2013. 
14 Hackett to Rose, Nictheroy, 20th november 1916. RAC, RF, RG 1.1, Series 305H, Sub-Series H, Box 15, Folder 133.

15 According to information available on the Oswaldo Cruz Institute website, Carlos Chagas realized the need to systematize the research in Mycology carried out in Manguinhos, as there was a great deal of international activity in this field in the period, and he appointed Fonseca for the task. Department of Mycology [online], available at: http://www.ioc.fiocruz.br/pages/departamentos/ departamento micologia.htm, [accessed: 17/08/2020].

16 RAC, RF, RG 10.2 Fellowship Recorder Cards, Series MNS Brazil, Fonseca, Olympio da.

17 Hackett to Pearce, Pará, December 17, 1919 (RAC, RF, RG 5, Series 1 - Correspondence, Sub-Series 2 - Project, Box 78, Folder 1110). According to Hackett, the Committee would have two members in São Paulo and three in Rio de Janeiro. Lina Faria also indicates the existence of the Committee Selection Committee for Rockefeller Foundation Fellowship Applicants in Brazil - which was formed, at a certain moment, by Carlos Chagas, Vital Brazil and Alexandre M. Pedroso (Faria, 2007, p. 104- 105, note 14).

18 Hackett to Wells, 5th January, 1921. RAC, RF, RG 5, Series 1 , Sub-Series 2 - Project, 305 Brazil - Hackett, L. W. (July-December), Box 113, Folder 1534.

19 Hackett to Wells, 5th January, 1921. RAC, RF, RG 5, Series 1, Sub-Series 2 - Project, 305 Brazil - Hackett, L. W. (July-December), Box 113, Folder 1534.

20 Heiser to Hackett, January 7, 1920. RAC, RF, RG 5, Series 1, Sub-Series 2 (1920 - 305 Brazil), Box 95, Folder 1307

21 It is interesting to underline that Fonseca was a RF fellowship holder between 1920 and 1922, shortly after the end of the First World War (1914-1918). In this context, the scientific and academic networks that the war had partially interrupted were being reconnected. According to historian Anne Rasmussen, "les guerres sont interprétée comme des obstacles au déroulement harmonieux de l'activité savant" (Rasmussen, 2007, p. 8). According to Peter Burke, also analyzing the post-war context, this presented itself as a new moment of international cooperation in science (Burke, 2012, p. 328-330)

22 RAC, RF, RG 10.2 Fellowship Recorder Cards, Series MNS Brazil, Fonseca, Olympio da

23 Mycology is dedicated to the study of topics related to fungi of importance to man and animals and their diseases. Micologia, [online], available at: https://sbmicrobiologia.org.br/ areas/micologia/, [accessed 02/04/2020].

24 William George MacCallum (1874-1944) was born in Dunnville (Ontario, Canada). He graduated in medicine from the Johns Hopkins University School of Medicine in 1897, where he started to work the following year. Between 1909 and 1917, he served as professor of pathology at Columbia University's College of Physicians and Surgeons. After this period, he returned to the Johns Hopkins as professor and chairman of the pathology department, a position he held until his retirement, in 1943. Medical Archives of the Johns Hopkins Medical Institutions. The William G. MacCallum Collection, [online], available at: https://medicalarchives.jhmi. edu:8443/papers/maccallum.html, [accessed 02/04/2020].

25 RAC, RF, RG 10.2 Fellowship Recorder Cards, Series MNS Brazil, Fonseca, Olympio da

26 Erwin F. Smith (1854-1927) was born in New York. He graduated in Biology from the University of Michigan in 1886 , the same year he started working in the Mycology Section of the United States Department of Agriculture (Bureau of Plant Industry). In 1889, he was promoted to head of Plant Pathology at the Bureau of Plant Industry. He worked for 40 years in the United States Department of Agriculture. USDA, Erwin Frink Smith Papers. [online], available at: https:// specialcollections.nal.usda.gov/guide-collections/erwinfrink-smith-papers, [accessed 02/04/2020].

27 RAC, RF, RG 10.2 Fellowship Recorder Cards, Series MNS Brazil, Fonseca, Olympio da

28 Charles Thom (1872-1956) was born in Minonk (Illinois). $\mathrm{He}$ received his doctorate from the University of Missouri in 1889. He worked at the United States Department of Agriculture between 1904 and 1942. In 1913, he moved to Washington to serve as head of the Microbiological Laboratory, Bureau of Chemistry. He was then Head of the Division of Soil Microbiology, Bureau of Chemistry and Soils (19271934) and Bureau of Plant Industry (1934-1942). The New York Botanical Garden. Charles Thom Papers (PP), [online], available at: https://www.nybg.org/library/finding_guide/ archv/thom ppf.html, [accessed 02/04/2020]; RAC, RF, RG 10.2 Fellowship Recorder Cards, Series MNS Brazil, Fonseca, Olympio da.

29 Raymond Jacques Adrien Sabouraud was born in Nantes in 1864. Graduated in medicine, Sabouraud played an important role in dermatology and mycology. In 1890, he enroIled in the basic bacteriology course at the Pasteur Institute, coordinated by Pierre Paul Emile Roux (1853-1933). In 1897, he was invited by the City Council of the City of Paris to head the Hospital Saint Louis's Lailer School. According to Paulo Murillo Neufeld, “(...) it was at this school and at Saint Louis Hospital that Sabouraud carried out most of his research on fungal diseases, elucidating many of the aspects related to the etiology, pathology, parasitology and treatment of these processes". Neufeld, Paulo Murillo (2018), Personagem da História da Saúde IV: Raymond Sabouraud, Revista Brasileira de Análises Clínicas, 50 (4), [online], available at: http:// www.rbac.org.br/artigos/volume-50-no-4-editorial/, [accessed 02/04/2020].

30 RAC, RF, RG 10.2 Fellowship Recorder Cards, Series MNS Brazil, Fonseca, Olympio da.

31 Alexandre Joseph Émile Brumpt (1877-1951) was a parasitologist. He received a PhD in Natural Sciences in 1901 and in Medicine in 1906. Between 1919 and 1948, he was professor of parasitology at the Faculty of Medicine of Paris. He conducted research in different countries around the world, including Brazil. Comité des travaux historiques et scientifiques. BRUMPT Emile Joseph Alexandre, [online], available at: https://cths.fr/an/savant.php?id=661\#, [accessed 02/04/2020].

32 Maurice Charles Pierre Langeron (1874-1950) was a French mycologist. He studied Natural Sciences at the Muséum National d'Histoire Naturelle in Paris. In 1930, he was appointed director of the Department of Mycology at the Parasitology Laboratory of the Faculty of Medicine of Paris. In 1942, he was appointed Research Director at the Center National de la Recherche Scientifique. Available at: https://en.wikipedia. org/wiki/Maurice_Langeron, [accessed 02/04/2020].

33 Masao Ota (1885-1945) was a dermatologist physician graduated from the University of Tokyo Medical School. Between 1935 and 1937, he served as Director of the Dermatological Clinic at the University of Tokyo (Kitamura, 1957). 
34 RAC, RF, RG 10.2 Fellowship Recorder Cards, Series MNS Brazil, Fonseca, Olympio da.

35 See RAC, RF, RG 10.2 Fellowship Recorder Cards, Series MNS Brazil, Fonseca, Olympio da; e Fonseca Filho, 1985, p. 25.

36 The Brazilian Institute for Research in the Amazon conducts scientific studies of the physical environment and living conditions in the Amazon region. Information about the Institute can be found at: http://portal.inpa.gov.br/index.php/ institucional.

37 Information about Olympio da Fonseca's professional career was found in Currículo do Dr. Olympio Oliveira Ribeiro da Fonseca (MAST - OF.T.5.002.1) e Prof. Olympio da Fonseca, filho (MAST - OF.T.5.002.2).

38 According to information available on the Fiocruz website, "[...] the Laboratory of Taxonomy, Biochemistry and Bioprospecting of Fungi of the Oswaldo Cruz Institute (LT$\mathrm{BBF} / \mathrm{IOC} /$ Fiocruz) performs the morphological, biochemical and molecular characterization of filamentous fungi in order to identify markers that assist classical taxonomy, the identification of potential diagnostic and chemotherapeutic targets and the prospection of new fungal bioinsecticides.

\section{BIBLIOGRAPHY}

Benchimol, Jaime L. (2003), “Adolpho Lutz: um esboço biográfico", História, Ciências, Saúde - Manguinhos, 10 (1), pp. 13-83.

Birn, Anne-Emanuelle (2006), Marriage of convenience: RockefeIler International Health and revolutionary Mexico, Rochester, University of Rochester Press.

Burke, Peter (2012), Uma história social do conhecimento - II: da Enciclopédia à Wikipédia, Rio de Janeiro: Zahar.

Castro Santos, Luiz Antonio de; Faria, Lina (2003), A reforma sanitária no Brasil: ecos da Primeira República, Bragança Paulista, EDUSF.

Castro Santos, Luiz Antonio de; Faria, Lina (2004), “A cooperação internacional e a enfermagem de saúde pública no Rio de Janeiro e São Paulo", Horizontes, 22 (2), pp. 123-150.

Cueto, Marcos (ed.) (1994), Missionaries of science: the Rockefeller Foundation and Latin America, Bloomington, Indiana University Press.

Cueto, Marcos; Palmer, Steven (2015), Medicine and Public Health in Latin America: a history, New York, Cambridge University Press.

Faria, Lina (2007), Saúde e Política: a Fundação Rockefeller e seus parceiros em São Paulo, Rio de Janeiro, Editora Fiocruz.

Faria, Lina; Costa, Maria Conceição da (2006). "Cooperação Científica Internacional: Estilos de Atuação da Fundação Rockefeller e da Fundação Ford", Dados - Revista de Ciências Sociais, 49 (1), pp. 159-191.

Farley, John (2004), To cast out disease: a history of the International Health Division of the Rockefeller Foundation (19131951), Nova York, Oxford University Press.
The researchers also aim to establish experimental models for studying the virulence of emerging fungi." Laboratory of Taxonomy, Biochemistry and Bioprospecting of Fungi of the Oswaldo Cruz Institute (LTBBF/IOC/Fiocruz) [online], available at: http://www.fiocruz.br/ioclabs/cgi/cgilua.exe/sys/ start.htm?sid=85, [accessed 17/08/2020].

39 CCFF "[...] carries out activities such as isolation of fungal strains from different ecosystems and substrates, taxonomic studies of different groups, development and improvement of methods of cultivation, characterization and preservation of fungal specimens. CCFF was founded in 1922 and constitutes a center for the conservation of biological resources, responsible for collecting relevant organisms for scientific studies, offering services of identification, deposit, preservation in different methods (mineral oil, water and lyophilized) and distribution of fungi, in addition to offering consultancy and training for human resources." OCl's Filamentous Fungus Culture Collection (CCFF) [online], available at: http:// www.fiocruz.br/ioc/cgi/cgilua.exe/sys/start.htm?sid=187, [accessed 17/08/2020].

Fee, Elizabeth (1987), Disease and Discovery: a History of the Johns Hopkins School of Hygiene and Public Health, 19161939, Baltimore, The Johns Hopkins University Press.

Fonseca Filho, Olympio Oliveira Ribeiro da (1985), Olympio Oliveira Ribeiro da Fonseca (depoimento, 1977). Rio de Janeiro, FGV/CPDOC - História Oral.

Kitamura, Kanehico (1957), "In memoriam Masao Ota (18851945)". Mycopathologia, 8 (2), pp. 164-167.

Korndörfer, Ana Paula (2013), "An international problem of serious proportions": A cooperação entre a Fundação Rockefeller e o governo do estado do Rio Grande do Sul no combate à ancilostomíase e seus desdobramentos (1919-1929)", Porto Alegre, Faculdade de Filosofia e Ciências Humanas, Pontifícia Universidade Católica do Rio Grande do Sul: tese em História.

Löwy, llana (2006), Vírus, mosquitos e modernidade: a febre amarela no Brasil entre ciência e política, tradução de Irene Ernest Dias, Rio de Janeiro, Editora Fiocruz.

Marinho, Maria Gabriela S. M. C (2001), Norte-americanos no Brasil: uma história da Fundação Rockefeller na Universidade de São Paulo (1934-1952), Campinas, São Paulo, Autores Associados; São Paulo, Universidade São Francisco, 2001.

Neufeld, Paulo Murillo (2018), "Personagem da História da Saúde IV: Raymond Sabouraud", Revista Brasileira de Análises Clínicas, 50 (4), [online], available at: http://www.rbac.org.br/ artigos/volume-50-no-4-editorial/, [accessed 02/04/2020].

Palmer, Steven (2010), Launching global health: the Caribbean odyssey of the Rockefeller Foundation, Ann Arbor, The University of Michigan Press, 2010.

Rasmussen, Anne (2007). "Réparer, réconcilier, oublier: enjeux et mithes de la démobilisation scientifique, 1918-1925", Histoire@Politique. Politique, culture, societé, Paris, 3, pp. 1-14. 